\title{
Die Orte der DMV-Jahrestagungen seit 1990
}

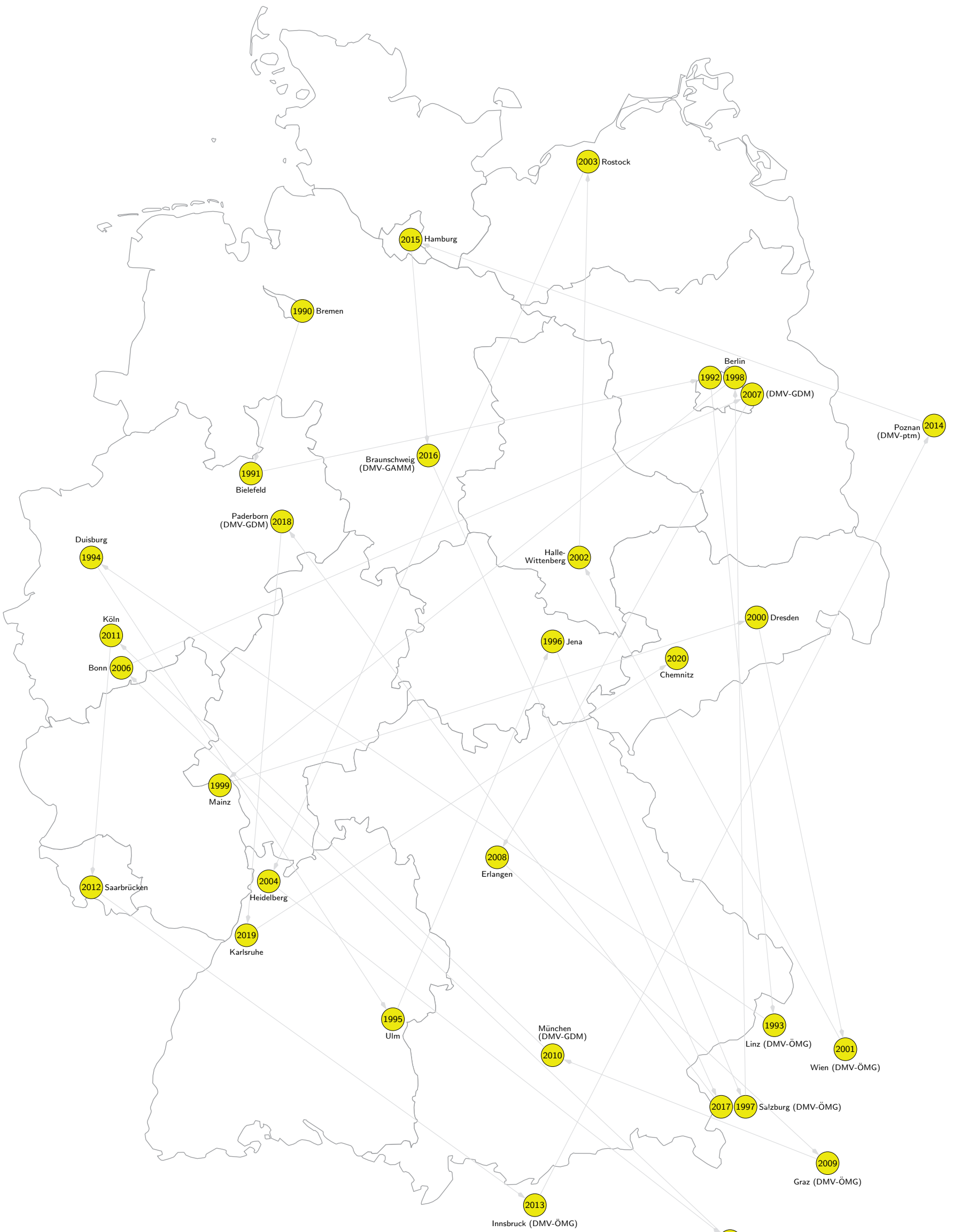

